\title{
Christianization of Fairies in Armenia
}

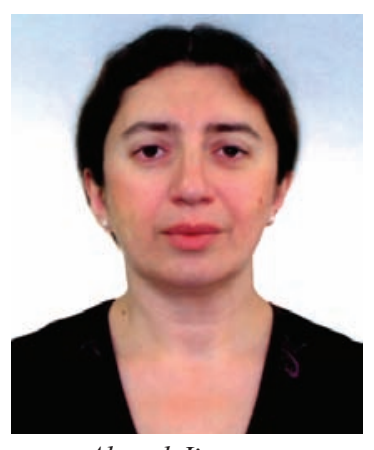

Alvard Jivanyan

\begin{abstract}
bout 1700 years ago Armenians were converted into Christianity. The new religion was brought into Armenia from Assyria and Asia Minor, preached by Gregory the Illuminator, the future bishop of the country, and was adopted as a state religion by Tiridates III, the haughty King of Armenia.
\end{abstract}

Tiridates hoped Christianity would make him independent from his two powerful and dangerous neighbors: Rome and Persia. Though an ally of Armenia, Rome was imposing his patronage on the country, trying to weaken it by making the coronation of Armenian kings the privilege of Rome. To an extent the Conversion would solve the problem, for Christian kings could not be chosen by Pagan Rome.

The Sassanian threat was no less real. A considerable part of Armenian nobility was Zoroastrian and would serve the Sassanians rather than an Armenian King appointed by the Romans. Conversion into Christianity, suggesting intolerance towards Zoroastrianism, would bring Armenian gentry together and distance them from Persia.

With the establishment of Christianity in Armenia the Early Church began to show intolerance towards any expression of paganism. Pavstos Buzand's History of Armenians, though rich in ridicule and criticism, gives a true and valuable picture of the newly converted nation still strongly attached to the pagan religion:

They were like children absorbed in their play and their minds were busy with vain and useless things ... They wasted their time on unworthy knowledge, pagan traditions and wild barbarous thoughts. They loved their myths and songs and they worshipped their old gods at night as if committing fornication (Buzand, 1987: 70).

Unforgiving towards pagan Gods, the early Church was more tolerant towards minor heathen spirits: it found it sufficient to declare that fairies were evil spirits, regarding them as various transformations of the devil. An outstanding Armenian scholar of the $5^{\text {th }}$ century, Yeznik Koghbatsi, in his Yeghts Aghandots (The Denial of Sects), denies the existence of other rational creatures apart from angels, devils, and humans: "The devil likes to show itself in different appearances, and people give names to them" (Koghbatsi, 1994: 81).

The tendency to introduce fairies as devils could be traced as late as the $14^{\text {th }}$ century. Gregory of Tatev, an Armenian philosopher and theologian, though did not identify fairies with devils, but spoke of their affinities, stating: "Like devils, fairies can deceive the humans with an illusion of false joy" (Alishan, 1910: 15).

Interestingly, a similar situation arose in Europe, in Ireland, for example. In Daith 


\section{O’ Hogain's An Encyclopedia of the Irish Folk Tradition we read:}

The monk who committed the ancient lore to writing had, from the beginning, been somewhat uncomfortable theologically when describing the otherworld of preChristian belief. At times the writers regarded it as a simple realm of story, at other times they felt compelled to reduce its characters to the plane of ancient history, but when its mythical and spiritual nature became too awkward to handle they resorted to demonizing it (O’Hogain, 1990: 187).

In England with the growth of Puritanism "The view of fairies became darker and the fallen angels began to be regarded as downright devils, with no mitigating features" (Briggs, 1979: 320).

But the common people had another attitude towards the fairy folk, quite different from that in Christian writings. Those Better than We was a euphemism for fairies current in Armenia until lately, very similar to the Irish laudatory Good People and Scottish Good Neighbours and Honest Folk.

Such euphemisms did not only suggest that people were scared of these wanton creatures, but also showed humans esteemed them as being of higher rank. In the province of Van, fairies were so favoured that G. Servantsian, writing on the possible etymology of the word pari/peri (fairy), suggested that it might be derived from bari (kind) (Servantsian, 1978: 45). The suggestion sounds plausible. Pari, however, in Armenian is a Persian borrowing. It is very tempting to suggest English fairy is a Persian borrowing, having a far more obvious commonality with pari or peri than with fata; this view, however, has long been denied as deceptive, though attractive (Keightley, 1981: 5).

In Armenia the belief in fairies was uniquely mirrored in naming. The name Pari was often given to a new-born girl in expectation that she should be a beauty. True, often the name was associative of ill-humour; irritable women in Artsakh villages were called Gizh Pari (Mad Fairy). The Artsakh tale Huri-Peri portrays the heroine in the following way:

There was and was not a very beautiful girl whose name was Huri-Peri. This girl was so beautiful that whoever saw her was astonished but she was so ill-tempered that nobody wanted to take her into marriage. She was very ill-tempered and her conduct was rude, objected to everything and would not get along with people, was loud-mouthed, shameless and obstinate (Hay zhoghovrdakan heqiatner, vol VI, 1973: 207).

According to Seriné in Van (Artchak) “it was a sin to cross one's face when seeing a mermaid, for water fairies are created by God to protect humans from Evil. On moonlit nights they come out of water and tread on the snakes' nests, killing them. If not for the fairies the world would be filled with these evil creatures (Seriné, 1978: 111). This was a rather strange mission for even today, Armenian folk beliefs have elements of snake worship. In fairy tales fairy princes and princesses frequently appear to humans in the shape of beautiful snakes. Further, in the same work we read: "The lake where the water 
spirits dwell, is blessed by God... On its bottom stands an inviolable church"(Serinй, 1978: 111). The dwelling of fairies in close neighborhood of a church speaks of the reconciliation of heathen creatures with Christianity.

Of interest, this issue can be looked upon in comparison with material from Scandinavian folklore. As Christiansen puts it:

Many references occur to the churches of fairies, to their divine services and to their priests. Thus there are stories about disputes between the fairy priest and the minister of the parish in consequence of the latter having declared that the fairies had no religion at all (Christiansen: 1958: 91).

According to a folk legend Gregory the Illuminator caught all the devs (fairies of huge size and revolting appearance) and threw them into a dungeon. The Lame Dev, however, begged Gregory to set him free, promising to serve at St. Karapet's monastery in Mush till the Judgment Day. It was his duty to gather the ashes left from the monastery fires and, walking two days' way to the town of Tigranakert, throw them into the river Ephratis (Servantsian, 1978: 75).

Similar legend material, common in Eastern and Southern Norway, is presented in Reidar Christiansen's list of legend types under type 5050 Fairies Prospect of Salvation (Christiansen, 1958: 89). Of interest, Irish fairies, too, grieved their isolation from the Christian community: "Having lost their places in heaven, the fairies were believed to be anxious to regain them," writes Dr. Daith O'Hogain. He mentions an Irish folk legend about fairies asking a traveling priest if they would ever gain salvation. Hearing a negative answer they began to wail pitifully (O'Hogain, 1990: 188).

A version of the legend, The Priest's Supper, is narrated by W.B. Yeats in Irish Folk and Fairy Tales:

Then said the little speaking fairy, while the rest came crowding after him from all parts, "Go and ask Father Horrigan to tell us whether our souls will be saved at the last day, like the souls of good Christians; and if you wish us well, bring back what he says without delay (Yeats, 1962: 12).

A number of folk legends try to relate the origin of fairies to the figure of Christ. Thus, according to a series of Biblical legends, fairies are the descendants of humans, who for trying to deceive Christ were cursed by him and their children became invisible kajks - evil fairies (Ghanalanyan, 1969: 356-357).

A popular legend suggests fairies take their origin from Noah's granddaughter. God had forbidden Noah and his sons to lie with their wives during the deluge. One of Noah's sons, however, disobeyed and a daughter was born to him. When the waters subsided, and it was time to leave the ark, Noah made up his mind to leave the new-born child in the ark. Then God's angel appeared and asked, "Noah, is there anyone inside?"

"No," was the answer.

"If there is someone," said the angel primly, "May it become invisible." 
So the girl became a huri-peri (fairy), approached men and multiplied the race of the fairies in our world (Bensй, 1972: 57).

Rather explicitly the Christianization of fairies can be seen in Armenian fairy tales. In The Tale of Prince Armen, a fairy, finding out her wings are stolen by a young girl, asks God to change her into a boy (Hay Zhoghovrdakan Heqiatner, vol IX 1968, 89). In fairy lores of Christian nations, fairies, as a rule, do not address God and are not members of Christian community.

It is notable that a similar process of adapting supernatural personnel to the dominant religion can be traced also in Muslim folklore. Peris and deevs, who most probably have arisen from the Zoroastrian mythology of ancient Persia, in Iranian fairy tales often address Allah and see themselves entirely dependent on him (Braginsky, 1977: 272).

The above said makes it possible to speak of the reconciliation of Christian religion with elements of paganism, as Diaramind O'Giollain puts it of "pre-Christian phenomena being Christianized and surviving non-Christian phenomena taking on a Christian frame of reference" (O'Giollain, 1991: 203). In other words we speak of syncretism when it is understood "positively, as a sign of tolerance" (van der Veer, 1994: 209).

The syncretism of fairy personages can be seen in Armenian medieval painting. Medieval Bible miniatures and decorations abound in fairy figures. The bird maidens on the title page of a 1390 Bible illuminated by Hovhammes Khisantsi have crosses hung from their necks.

Thus the Christianization of fairies stimulated the survival of fairy beliefs during centuries of Christianity. Such is the result of the interaction of heterogeneous beliefs belonging to chronologically different layers.

\section{References Cited:}

1. Alishan Ghevond. Hin havatq hayots. Venetik: S.Ghazar, 1910 (in Armenian).

2. Вensй Harq. Hay azgagrutyun yev banahyusutyun, vol. 3. Yerevan: Hayastani GA hratarakchutyun, 1972.

3. Briggs Katherine. Dictionary of Fairies. Harmondsworth: Penguin Books, 1979.

4. Buzand Pavstos. Patmutyun hayots. Yerevan: Yerevani hamalsarani hratarakchutyun, 1987 (in Armenian).

5. Christiansen Reidar Th. The Migratory Legends: A Proposed List of Types with a Systematic Catalogue of the Norwegian Variants. Helsinki: Academia Scientiarum Fennica, 1958.

6. Ghanalanyan Aram. Avandapatum. Yerevan: Hayastani GA hratarakchutyun, 1969 (in Armenian).

7. Hay zhoghovrdakan heqiatner. Vol.1-15. Yerevan: Hayastani GA hratarakchutyun, 1959-1999 (in Armenian).

8. O'Giollain Diarmuid. The Fairy Belief and Official Religion in Ireland. // The Good 
People. New Fairylore Essays, Peter Narvaez (ed.). New York and London, 1991.

9. O'Hogain Myth, Legend and Romance. An Encyclopaedia of Irish Folk Tradition. Ryan Publishing, 1990.

10. Keightley Thomas. Fairy Mythology. Salem House Publishers: 1983.

11. Koghbatsi Yeznik. Yeghts aghandots. Yerevani hamalsarani hratarakchutyun, 1994 (in Armenian).

12. Serinй Artchak. Hay azgagrutyun yev banahyusutyun. Vol. 8. Yerevan: Hayastani GA hratarakchutyun, 1978 (in Armenian).

13. Servantsian Garegin. Grots-Brots. Yerevan: Hayastani GA hratarakchutyun, 1978 (in Armenian).

14. Thompson Stith. Motif-Index of Folk-Literature ( $1^{\text {st }}$ edn., 1955-1958). Bloomington \& London: Indiana University Press, 1975.

15. van der Veer Peter. Syncretism, Multiculturalism and the Discourse of Tolerance. // The Politics of Religious Synthesis. (eds.) CH. Steward and R.Shaw. London: Routledge, 1994.

16. Yeats W.B. Irish Fairy and Folk Tales. New York: The Modern Library, 1970.

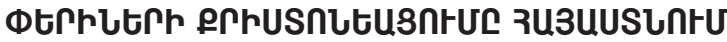

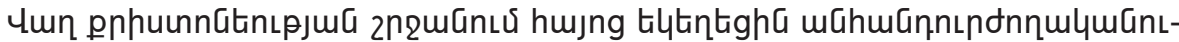

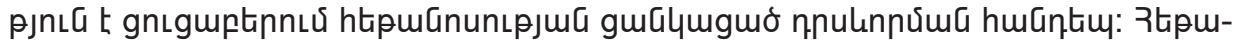

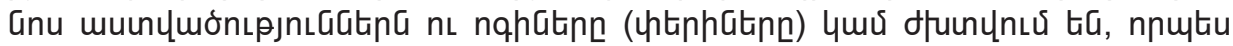

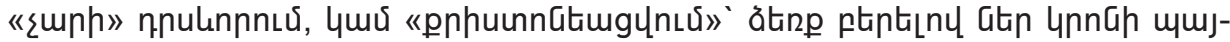

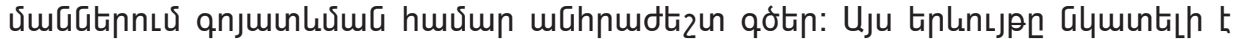

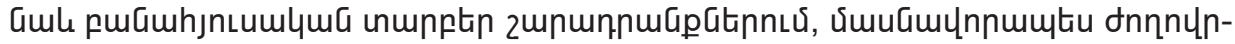

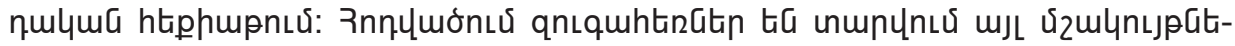

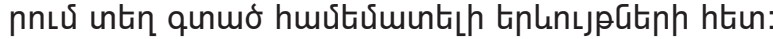

